\title{
Prioritní a prioritní nebezpečné látky v říčních sedimentech v blízkosti Prahy
}

\section{STANISLAV JURÁŇ, PAVEL SEDLÁČEK, KATEŘINA SOVOVÁ, LUCIE VYSLOUŽILOVÁ}

Klíčová slova: povodně - chemický stav - říční sedimenty - prioritní a prioritní nebezpečné látky

\section{SOUHRN}

Príspěvek představuje část projektu Čistá voda - zdravé město, který se zabýval mimo jiné hodnocením kvality říčních sedimentů z pohledu zátěže prioritními a prioritními nebezpečnými látkami (PPN látky), které mohou např. během povodní ohrozit vodní ekosystémy i lidské zdraví. Projekt je financován z Evropských strukturálních a investičních fondů prostřednictvím Operačního programu Praha - pól růstu ČR a byl navržen s trváním 2,5 roku s předpokládaným ukončením v pololetí roku 2020. Lokality pro vzorkování říčních sedimentů byly vytipovány v zájmovém území hlavního města Prahy, v povodí vodních toků nad hlavním městem, na řece Berounce, Sázavě a Vltavě. Protože v České republice ani v Evropské unii neexistuje legislativa stanovující limitní hodnoty koncentrací prioritních a prioritních nebezpečných látek $v$ sedimentech, byly pro hodnocení použity limity právních předpisů Kanady a Austrálie.

\section{ÚVOD}

Projekt obsahuje pět částí (konceptů řešení). Smyslem řešení Konceptu III s názvem „Predikce možného výskytu nebezpečných chemických látek při haváriích a povodních, riziko úniků látek závadných vodám a preventivní opatření - podklad k havarijnímu plánu“, je zlepšení informovanosti o výskytu látek definovaných jako látky prioritní a prioritní nebezpečné (dále jen PPN látky) a vyhodnocení rizika pro hlavní město s ohledem na jejich možný výskyt a nakládání. Řešení se zaměřuje na specifickou skupinu chemických látek, která z hlediska širrení a akumulace v povodí vodních toků a jejich ekosystémů představuje nejvyšší riziko ohrožení.
Prioritní a prioritní nebezpečné látky jsou významným rizikem pro vodní prostředí, vyznačují se akutní a chronickou toxicitou pro vodní organismy, akumulují se ve vodních ekosystémech, způsobují úbytek přirozených biologických stanovišt a mohou ohrožovat i lidské zdraví. Látky byly poprvé definovány v roce 2001 v príloze č. X Rámcové směrnice o vodní politice [1] a byly následně doplněny Směrnicí Evropského parlamentu a Rady 2013/39/EU [2]. V rámci řešeného konceptu byla využita řada odborných databází a informací [3] a uskutečnil se monitoring těchto látek v říčních sedimentech.

\section{SOUČASNÝ STAV}

Výskyt PPN látek je ve vodních tocích monitorován pro potřeby plánování a posouzení chemického stavu vod [4] - jako součást dobrého stavu vod, kterého by mělo být postupně dosaženo. Dosavadní poznatky uvedeného monitoringu jsou obsaženy $v$ tabulce 1 .

Z dosavadních výsledků vyplývá, že PPN látky sledované v povrchových vodách ČR se vyskytují prevážně ve velmi nízkých koncentracích na úrovni mezí stanovitelnosti daného monitoringu (MS). Pokud jsou zjištěny hodnoty nad MS, pak většinou nepřesahují NEK-RP (norma environmentální kvality vyjádřená jako roční průměrná hodnota) a NEK-NPK (norma environmentální kvality vyjádřená jako nejvyšší prípustná koncentrace).

Při orientačním porovnání s hodnotami NEK [5] jsou v povrchových vodách nejčastěji překračovány hodnoty NEK-RP anebo NEK-NPK u látek patřícím do skupiny těžkých kovů $(\mathrm{Hg}, \mathrm{Cd}, \mathrm{Ni})$, do skupiny polycyklických aromatických uhlovodíků - PAU (benzo(a)pyren a benzo(ghi)perylen, benzo(b)fluoranthen, benzo(k)fluoranthen, fluoranthen) a dále isoproturon, diuron, pyren a bromovaný difenylether.

Tabulka 1. Vodní útvary povrchových vod v dilčich povodí zájmového území, nedosahující dobrý chemický stav vod Table 1. The sub-basins of the area of interest where surface water bodies not in good chemical status

$\begin{array}{ll}\text { Dílčí } & \text { Vod. útvary nedosahující } \\ \text { povodí } & \text { dobrý chem. stav vod [\%] }\end{array}$

Horní Vltava 15

Dolní Vltava 16

Berounka 30

\section{Prioritní a prioritní nebezpečné látky}

fluoranthen, benzo[a]pyren, benzo[b]fluoranthen, benzo[k]fluoranthen, bromovaný difenylether, nikl a jeho sloučeniny, rtut' a jeho sloučeniny, benzo[g,h,i]perylen

fluoranthen, benzo[a]pyren, benzo[b]fluoranthen, benzo[k]fluoranthen, bromovaný difenylether, nikl a jeho sloučeniny, rtut a jeho sloučeniny

pyren, izoproturon, kadmium a jeho sloučeniny, fluoranthen, benzo[a]pyren, benzo[b]fluoranthen, benzo[k]fluoranthen, bromovaný difenylether, rtut’ a jeho sloučeniny, diuron, nikl a jeho sloučeniny, benzo[g,h,i]perylen, benzo[g,h,i]perylen 
Vodní toky jsou recipientem PPN látek, které mj. mohou být do vodních toků vypouštěny spolu s odpadními vodami. Vypouštění odpadních vod s povoleným obsahem těchto látek nevede bezprostředně k překračování jakostních limitů v toku. Tento stav se však může změnit pohybem rríčních sedimentů, ve kterých mohou být tyto látky ve zvýšené miře akumulovány. Riziko nadlimitních koncentrací PPN látek v povrchových vodách je tak zvýšené za povodní a při vysokých vodních stavech, kdy dochází k pohybu sedimentů a k uvolňování látek $v$ nich obsažených. Vodní toky jsou prostřednictvím odpadních vod zatěžovány nejvíce těžkými kovy a látkami ze skupiny PAU. Látky ze skupiny adsorbovatelné organicky vázané halogeny - AOX [6] se nedají věrohodně hodnotit - jedná se o dnes běžně používaný „všeobecný ukazatel“, pro který existují sice limity, ale jednotlivé látky mohou být rozsahem značně více či méně rizikové a provedená hodnocení nelze proto považovat za objektivní.

Hodnocení sedimentů provedené v zájmové oblasti mělo za cíl doložit, jaké PPN látky se $v$ říčních sedimentech akumulují v nadlimitních koncentracích, které by mohly být pro vodní tok a jeho ekosystémy rizikem a potažmo by mohly ohrozit kvalitu povrchových vod v hlavním městě.

\section{ROZSAH MONITORINGU ŘÍČNÍCH SEDIMENTU゚ A LABORATORNÍCH ANALÝZ}

Výzkumný ústav vodohospodářský T. G. Masaryka, v. v. i., se zabýval odběrem vzorků říčních sedimentů v rámci uvedeného řešení Konceptu III [7] v období let 2018 až 2019. V projektu bylo předně nutné na základě zadání řešit zainteresovanou oblast hlavního města Prahy a tím pokrýt povodí vodních toků, kterými by se mohly PPN látky do Prahy dostat. Před samotným zahájením odběrů vzorků říčních sedimentů proběhlo vytipování vhodných míst v zájmovém území Středočeského kraje $v$ blízkosti hlavního města. Kritériem bylo získat lokality, které by pokryly zdroje vypouštějící odpadní vody s možným obsahem PPN látek do vodních toků zájmového území. Dalším velmi důležitým kritériem, které významně ovlivnilo výběr vlastních lokalit, byla znalost míst, která umožňují akumulaci říčních sedimentů. Protože sedimenty se ve zvýšené miře vyskytují ve vodních tocích se sníženou rychlostí vody, která je následně príčinou sedimentace plavených částic, byla vybrána místa v nadjezí vodních toků. Posledním kritériem byla samotná prístupnost odběrných míst. Na základě uvedených kritérií byla vybrána čtyři odběrná místa - lokality (obr. 1):

- VItava-Štěchovice nad jezem, místo u hráze vodního díla,

- VItava-Modřany nad jezem, jako závěrné místo, ve kterém se předpokládá případné ovlivnění z prítoků řek Berounky a Sázavy,

- Berounka-Černošice nad jezem, významný levobřežní prítok Vltavy, místo v nadjezí elektrárny v Černošicích,

- Sázava-Žampach nad jezem, významný pravobřežní př́tok VItavy.

Pro odběry řičních sedimentů ve větších hloubkách byly využity služby potápěčů, společnosti MT facility a lod' společnosti Povodí Vltavy, s. p. (obr. 2).

Vzorky říčních sedimentů byly odebírány ručním odběrákem na teleskopické tyči nebo pomocí odběráku pro dnové sedimenty (typ Ekman-Birge) na laně. V odběrném místě Vltava-Štěchovice byl sediment odebrán potápěči do kbelíku na laně. Odebraný ríční sediment byl následně ve všech prípadech odvodněn. Reprezentativní množství sedimentu bylo pomocí lopatky přemístěno do plastových vzorkovnic o objemu 2 I. Vzorky byly následně umístěny do plastových chladicích boxů a takto inned po ukončení odběrů transportovány do laboratoře k laboratorním analýzám.

Laboratorní analýzy byly prováděny na základě výběrového řizení komerční laboratoří ALS Czech Republic, s. r. O., se sídlem Praha-Vysočany. Výsledky laboratorních analýz z koncentracemi PPN látek $v$ sušině byly predány $v$ podobě předávacích protokolů.

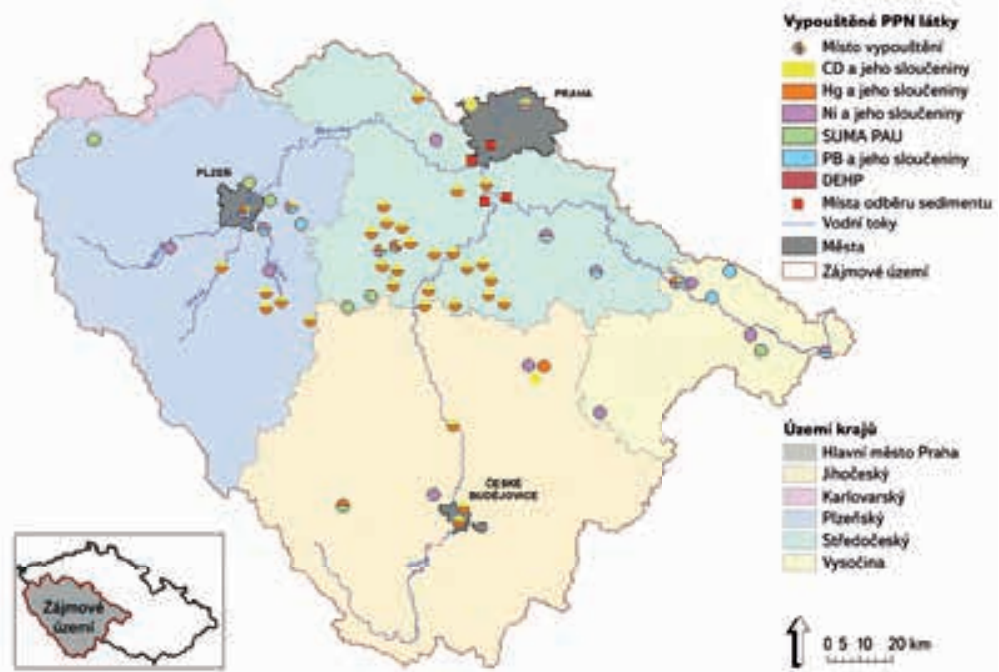

Obr. 1. Zájmové území s vypouštěním odpadních vod s výskytem PPN látek a odběrná místa říčních sedimentů

Fig. 1. Area of interest with discharges of the PPH substances and river sediment sampling sites
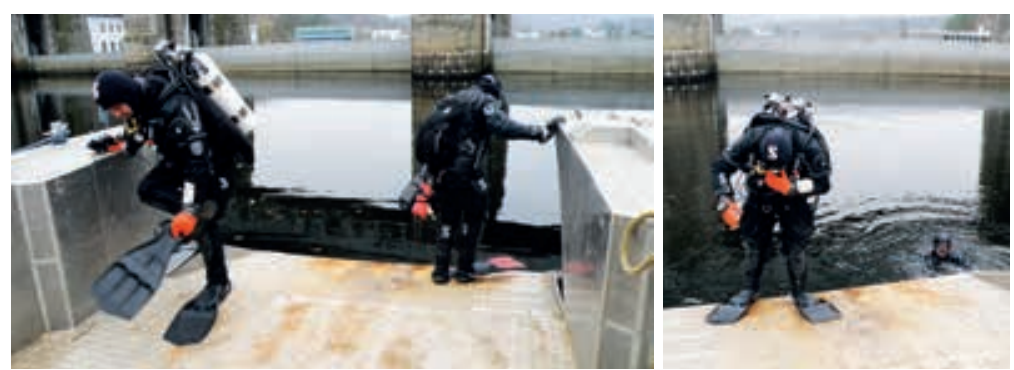

Obr. 2. Potápěči při odběru řičních sedimentů

Fig. 2. Divers taking river sediments

Celkem byly prováděny laboratorní analýzy pro všechny PPN látky v každém odebraném vzorku říčního sedimentu. Za dobu řešení projektu bylo odebráno z uvedených odběrných míst celkem 48 vzorkủ ríčních sedimentů (čtyři lokality, šest sérí odběrů a dva vzorky na lokalitu - litorál + proudnice vodního toku).

\section{VÝSLEDKY A HODNOCENÍ}

Prvotní hodnocení laboratorních analýz se zabývalo tím, které PPN látky se vyskytovaly nad mezí stanovitelnosti. Z výsledkư vyplývá, že v monitorovaných místech byly $v$ říčních sedimentech zjištěny koncentrace níže uvedených látek nad mezí stanovitelnosti (MS), viz následující tabulka 2.

Z uvedených celkem 11 PPN látek a skupin látek se látka PFOS vyskytovala nad mezí stanovitelnosti pouze ve dvou monitorovaných místech (Berounka-Černošice nad jezem a Sázava-Žampach nad jezem), a to v koncentracích překračujících tuto hodnotu o cca 20 \% ve dvou vzorcích. V ostatních vzorcích říčních sedimentů byly hodnoty PFOSu pod mezí stanovitelnosti.

$\mathrm{U}$ benzenu byly zjištěny koncentrace nad hodnotou MS rovněž pouze na dvou lokalitách (VItava-Modrany nad jezem ve čtyřech vzorcích a Sázava-Žampach nad jezem v jednom vzorku). Nejvyšší naměřená hodnota byla asi $3 \times$ vyšší než MS.

Látka DEHP se vyskytla nad mezí detekce ve třech lokalitách (Vltava-Štěchovice nad jezem ve dvou vzorcích, Berounka-Černošice nad jezem v jednom vzorku a Sázava-Žampach nad jezem v sedmi vzorcích říčních sedimentů). Nejvyšší naměřené hodnoty byly asi 3,5× vyšší než MS. 
Ostatní PPN látky uvedené v tabulce 2 se vyskytovaly nad hodnotou MS na všech čtyřech lokalitách, a to ve zvýšených koncentracích. Protože v České republice ani v Evropské unii neexistuje legislativní nástroj stanovující limitní hodnoty pro koncentrace polutantů v řičních sedimentech, byly pro účely dalšího hodnocení použity hodnoty používané v Kanadě a v Austrálii, viz následující tabulka 3 [8].

Z australské legislativy jsou uvedeny hodnoty v současnosti platné i hodnoty z roku 2000, které byly platné do roku 2018, protože některé látky již ve stávající legislativě nejsou. Všechna data byla převzata ze stránek Australské vládní iniciativy (Australian Government Initiative) [9]. Ze srovnání aktuálních limitů a limitů platných do roku 2018 je zřejmé, že většina hodnot zůstala beze změny, pouze byly některé hodnoty vypuštěny.

V aktuální směrnici je DGV výchozí směrná hodnota. Tato hodnota udává koncentraci, pod níz je nízké riziko výskytu nežádoucích vlivů a má být používána k ochraně vodního ekosystému. GV-high je dodatečná horní směrná hodnota udává koncentraci, při které Ize očekávat nepř́znivé účinky související s toxicitou.

Tabulka 2. Zjištěné monitorované PPN látky v říčnich sedimentech nad mezístanovitelnosti (MS) a presnost výsledků laboratorních analýz udávaných společností ALS v $\mu$ gg/kg sušiny Table 2. PPN substances in river sediments above the limit of determination and accuracy of results of laboratory analyses reported by ALS company

\section{Č. PPN látky podle NV 401/2015 Sb.}

MS $[\mu \mathrm{g} / \mathrm{kg}]$
Přesnost výsledků analýz podle společnosti ALS, s. r. o. [\%]

\begin{tabular}{llcc}
\hline 2 & anthracen & 10 & \pm 30 \\
\hline 4 & benzen & 10 & \pm 40 \\
\hline 6 & Cd a jeho sloučeniny & 400 & \pm 20 \\
\hline 12 & di-(2-ethylhexyl)ftalát (DEHP) & 800 & \pm 35 \\
\hline 15 & fluoranthen & 10 & \pm 20 \\
\hline 20 & Pb a jeho sloučeniny & 1000 & \pm 20 \\
\hline 21 & Hg a její sloučeniny & 10 & \pm 30 \\
\hline 23 & naftalen & 10 & \pm 20 \\
\hline 35 & Ni a jeho sloučeniny & 160 & \pm 30 \\
\hline
\end{tabular}

Tabulka 3. Kvalita sedimentů legislativně stanovená pro Kanadu a Austrálii; koncentrace jsou vztaženy k sušině sedimentu

Table 3. The sediment quality legislation limits in the Canada and Australia

\section{Kanada}

\section{č.} PPNL Název PPN látky

ISQG $[\mu \mathrm{g} / \mathrm{kg}]$

PEL $[\mu \mathrm{g} / \mathrm{kg}]$

Austrálie aktuální

\begin{tabular}{|c|c|c|c|c|c|c|c|}
\hline $\begin{array}{l}\text { č. } \\
\text { PPNL }\end{array}$ & Název PPN látky & 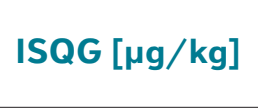 & PEL $[\mu \mathrm{g} / \mathbf{k g}]$ & DGV $[\mu \mathrm{g} / \mathrm{kg}]$ & $\begin{array}{l}\text { GV-High } \\
{[\mu \mathrm{g} / \mathrm{kg}]}\end{array}$ & $\begin{array}{l}\text { ISQG-Low } \\
{[\mu \mathrm{g} / \mathrm{kg}]}\end{array}$ & $\begin{array}{l}\text { ISQG-High } \\
{[\mu \mathrm{g} / \mathrm{kg}]}\end{array}$ \\
\hline 2 & anthracen & 46,9 & 245 & & & 85 & 1100 \\
\hline 6 & $\mathrm{Cd}$ a jeho sloučeniny & 600 & 3500 & 1500 & 10000 & 1500 & 10000 \\
\hline 15 & fluoranthen & 111 & 2355 & & & 600 & 5100 \\
\hline 20 & $\mathrm{~Pb}$ a jeho sloučeniny & 35000 & 91300 & 50000 & 220000 & 50000 & 220000 \\
\hline 21 & Hg a její sloučeniny & 170 & 486 & 150 & 1000 & 150 & 1000 \\
\hline 22 & naftalen & 34,6 & 391 & & & 160 & 2100 \\
\hline 23 & $\mathrm{Ni}$ a jeho sloučeniny & & & 21000 & 52000 & 21000 & 52000 \\
\hline 28 & PAU (suma) & & & 10000 & 50000 & 10000 & 50000 \\
\hline
\end{tabular}

\section{Vysvětlivky k tabulce:}

Limity platné v Kanadě byly převzaty ze stránek Kanadské rady ministrů životniho prostředí (Canadian Council of Ministers of the Environment) [8]. Hodnota ISQG (interim sediment quality guideline) je navržena jako celková koncentrace látky v povrchovém sedimentu a je určena pro hodnocení potenciálu biologických účinkủ. Hodnota PEL (probable exposure limit) definuje hranici, nad kterou lze očekávat častý výskyt nepríznivých účinkü.
Austrálie pưvodní 
Cd a jeho sloučeniny

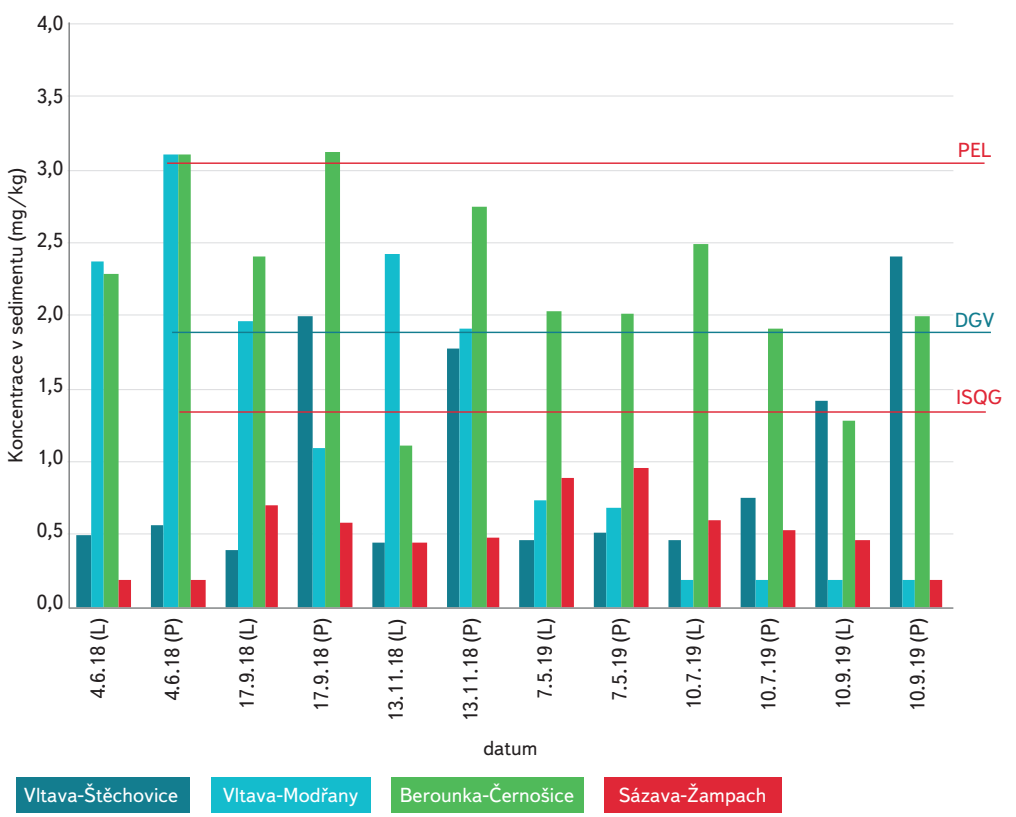

Pozn:: L - litorál, P - proudnice

Obr. 3. Koncentrace $\mathrm{Cd}$ a jeho sloučenin v řičních sedimentech

Fig. 3. Concentration of $\mathrm{Cd}$ and its compounds in river sediments

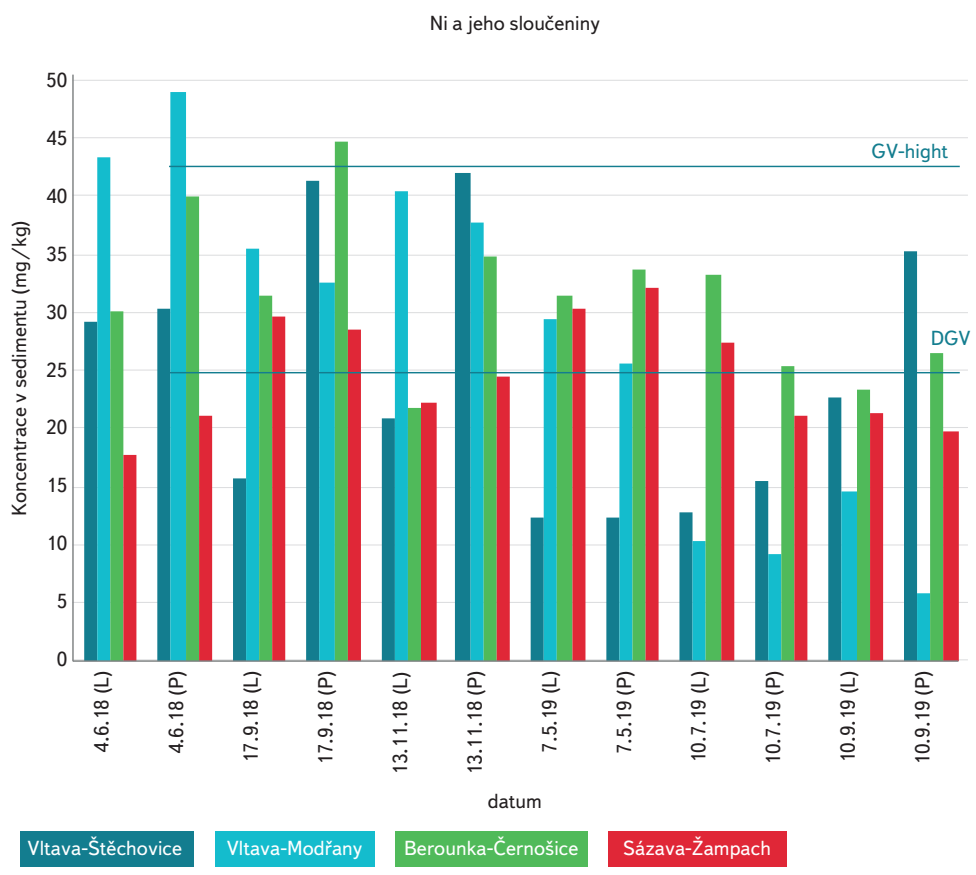

Pozn.: L - litorál, P - proudnice

Obr. 4. Koncentrace Ni a jeho sloučenin v říčních sedimentech

Fig. 4. Concentration of $\mathrm{Ni}$ and its compounds in river sediments

V již neplatné australské směrnici byla ISQG doporučená směrná hodnota kvality sedimentu. Hodnoty "low" a "high" odpovídají velikosti účinků podle US National Oceanic and Atmospheric Administration (response.restoration.noaa. gov/sites/default/files/SQuiRTs.pdf).

Pro přehlednost byly výsledné koncentrace jednotlivých PPN látek vyskytujících se $v$ říčních sedimentech nad mezí stanovitelnosti zobrazeny $v$ grafech; níže jsou zobrazeny grafy s výsledky analýz těžkých kovů - Cd, Ni a Hg (obr. 3-5).

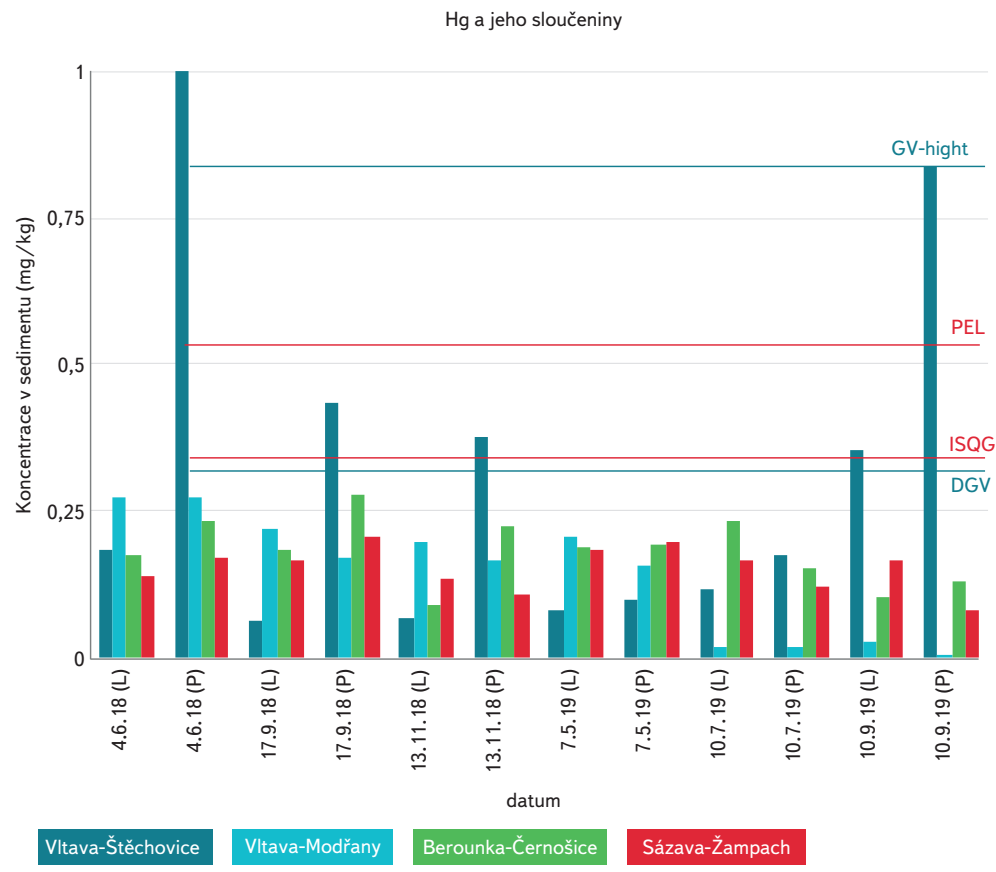

Pozn.: L - litorál, P - proudnice

Obr. 5. Koncentrace $\mathrm{Hg}$ a jejích sloučenin v ríčních sedimentech

Fig. 5. Concentration of $\mathrm{Hg}$ and its compounds in river sediments

\section{ZÁVĚR}

Uvedená část projektu se zabývala hodnocením říčních sedimentů, které mohou za zvýšených vodních stavů uvolňovat PPN látky akumulované v sedimentech. Protože se $v$ prípadě říčního ekosystému jedná o interakci dvou odlišných složek, kde pro vodu existují dané limity a pro sediment ne, je dále žádoucí zabývat se společným hodnocením. Lze předpokládat, že další podrobný monitoring uvedených složek by mohl pomoci najít řešení, kde dobrému chemickému stavu vod odpovídá "definovaný stav sedimentů". Způsoby hodnocení rizik pro říční ekosystémy vlivem působení chemických látek a hledání společných standardů se vyvíjí a znalost stavu nám hledání může usnadnit.

Asi pouze 1/4 definovaných PPN látek se vyskytuje $v$ ríčních sedimentech nad mezemi stanovitelnosti. Z hodnocení vyplývá, že až na výjimky jsou téměř všechny prioritní a prioritní nebezpečné látky, vyskytující se v námi monitorovaných říčních sedimentech nad mezemi stanovitelnosti, současně i látkami vyskytujícími se v koncentracích, které by mohly znamenat riziko výskytu nežádoucích vlivů při ochraně vodních ekosystémů a zdraví obyvatel. Z provedeného monitoringu Ize usuzovat, že mezi PPN látky, vyskytující se v říčních sedimentech ve zvýšených koncentracích na všech monitorovaných lokalitách, patří především olovo, anthracen a naftalen. Tyto látky se budou s velkou pravděpodobností vyskytovat $v$ nadlimitních koncentracích při zvýšeném pohybu sedimentů v povrchových vodách.

\section{Literatura}

[1] Směrnice Evropského parlamentu a Rady 2000/60/ES.

[2] Směrnice Evropského parlamentu a Rady 2013/39/EU.

[3] JURÁŇ, S., FOREJTNÍKOVÁ, M., VYSLOUŽILOVÁ, L. a SOVOVÁ, K. Čistá voda - zdravé město: Využitelnost stávajícího systému sběru informací pro naplnění cílů projektu. Vodohospodářské technicko-ekonomickéinformace, 2019, roč. 61, č. 6, s. 24-31. ISSN 0322-8916.

[4] Plánování v oblasti vod. Online. Dostupné z: http://www.pvl.cz/planovani-v-oblasti-vod 
[5] Nařízení vlády č. 401/2015 Sb., o ukazatelích a hodnotách prípustného znečištění povrchových vod, náležitostech povolení $k$ vypouštění odpadních vod do vod povrchových a do kanalizací a o citlivých oblastech.

[6] Halogenované organické sloučeniny (AOX). Online. Dostupné z: https://arnika.org/halogenovane organicke-slouceniny-aox

[7] JURÁŇ, S. Analýza proveditelnosti. Čistá voda - zdravé město. Koncept č. III, Brno, 2018.

[8] Canadian Council of Ministers of the Environment. Online. Dostupné z: https://www.canada.ca/ en/environment-climate-change/services/water-overview.html

[9] Australian Government Initiative. Online. Dostupné z: https://www.waterquality.gov.au/guidelines/ anz-fresh-marine: Australian and New Zealand guidelines for fresh and marine water quality.

\section{Autoři}

Ing. Stanislav Juráň

网 stanislav.juran@vuv.cz

\section{Ing. Pavel Sedláček}

冈 pavel.sedlacek@vuv.cz

Mgr. Kateřina Sovová, Ph.D.

冈katerina.sovova@vuv.cz

Ing. Lucie Vysloužilová

凶lucie.vyslouzilova@vuv.cz

Výzkumný ústav vodohospodářský T. G. Masaryka, v. v. i.

Příspěvek prošel lektorským řízením.
PRIORITY AND PRIORITY

HAZARDOUS SUBSTANCES IN THE RIVER SEDIMENTS NEAR PRAGUE

JURAN, S.; SEDLACEK, P.; SOVOVA, K.; VYSLOUZILOVA, L.

TGM Water Research Institute, p.r.i.

Keywords: flooding - chemical status - river sediments priority and priority hazardous substances

The report presents a part of the Clean Water - Healthy City project, which deals with the assessment of the river sediments quality with view of the load of priority and priority hazardous substances (PPH substances) which may endanger the aquatic ecosystems and human health during the flood. There were selected locations for the sampling of river sediments in the area of interest of the capital (watercourses above the capital) on the rivers Berounka, Sázava and VItava. As there is no legislation in the Czech Republic or the European Union setting limit values for priority and priority hazardous substances concentrations in sediments, the limits of Canada and Australia legislation were used for evaluation. 